\title{
Modifying Electoral Authoritarianism. What the 2016 Parliamentary Elections Tell us about the Nature and Resilience of the Putin Regime
}

\author{
David White \\ University of Birmingham, UK \\ d.j.white.1@bham.ac.uk
}

\begin{abstract}
Through a focus on the 2016 Russian parliamentary election, this article seeks to assess the strength of the Putin regime and the nature of the system itself. In contrast to those who have heralded its imminent decline, it is argued that the regime continues to display great resilience, the election providing evidence of the regime's adaptability and its ability to cope with challenges. The nature of the regime is also questioned. It has become commonplace for scholars to refer to Russia's political system under the presidency of Vladimir Putin as "electoral authoritarian". The article examines the function of elections in such systems, with a particular emphasis on the way in which elections provide the regime with legitimacy. The conduct and outcome of the elections not only points to the confidence and resilience of the Putin regime but might also suggest that a declining reliance on elections to sustain the regime may lead to a re-appraisal of the electoral authoritarian model as a compelling conceptualization of the Russian political system.
\end{abstract}

\section{Keywords}

Russia - electoral authoritarianism - parliamentary elections - legitimacy

\section{Introduction}

In September 2016, elections took place to the lower house of Russia's federal legislature, the State Duma. One would, however, have been forgiven for missing the event. Indeed, opinion polls carried out in Russia during the summer 
of 2016 revealed that two-thirds of the population were unaware that parliamentary elections were being held. ${ }^{1}$ The elections had been brought forward from December, the month in which all parliamentary elections had been held since the collapse of the Soviet Union. The campaign was therefore largely carried out during August when most Russians were perhaps more likely to choose the delights of the dacha over the drudgery of campaigning. The predictable outcome was summarized concisely by a newspaper headline as "boring elections with cheerful results". ${ }^{2}$ The results certainly brought a good deal of cheer to the Kremlin. According to the official results, United Russia (UR), whilst only increasing its share of the party list vote from 49.3 to 54.2 percent, nonetheless increased its representation in the Duma from 238 to 343 seats, thereby controlling over three-quarters of the parliament's 450 seats. The Putin administration would also have been pleased with the notably lower level of domestic and international criticism of the conduct of the electoral process in comparison with the flawed elections of 2011. More importantly it would have been delighted with the total lack of street protests once the results had been announced, in marked distinction to the unprecedented demonstrations that took place in the wake of the 2011 elections.

Institutions of representation in authoritarian systems have been dismissed as "insignificant window dressing. ${ }^{3}$ Schedler concedes that elections "make for lovely decorations in the shop windows of authoritarian regimes". ${ }^{4}$ However, as will be discussed below, whilst the role of elections in non-democratic settings such as Russia may not be immediately obvious, they are much more than window dressing. Indeed, they are integral to the maintenance of regime stability and serve as an indicator of the regime's resilience. Moreover, for scholars of authoritarian systems, elections provide a wealth of information about the relative strength and the nature of the system being studied. This article therefore focuses on two central questions relating to the resilience and nature of the Putin regime in the light of the conduct and outcome of the September 2016 parliamentary election. Firstly, what does the election tell us

1 Levada-Center,"Predstoyashchie vybory i obraz nyneshnei gosdumy”, 18 July 2016, http:// www.levada.ru/2016/07/18/predstoyashhie-dumskie-vybory-i-obraz-nyneshnej-gosdumy/ (accessed 26 September 2016).

2 Mikhail Rostovsky, "Skuchnaya kampaniya s neskuchnymi itogami", Moskovsky komsomolets, http://www.mk.ru/politics/2016/og/18/po-rezultatam-vyborov-v-gosdumu-putin-primet-vaz hnye-resheniya.html (accessed 18 September 2016).

3 Jennifer Gandhi, Political Institutions under Dictatorship (New York: Cambridge University Press, 2008): xxi.

4 Andreas Schedler, The Politics of Uncertainty: Sustaining and Subverting Electoral Authoritarianism (Oxford: Oxford University Press, 2013): 69. 
about the health and resilience of the Putin regime? Secondly, what does the election tell us about the nature of the regime and does electoral authoritarianism remain the most compelling conceptualization of the Russian political system?

In contrast to those who have pointed to the vulnerability of the Putin regime to external shocks, a faltering economy and the limited long-term feasibility of mobilizing support through national-patriotic appeals, ${ }^{5}$ I argue that the conduct and outcome of the September 2016 election provides evidence of the regime's adaptability and its ability to cope with challenges: factors that help to explain its resilience and durability. The electoral process in 2016 points to a growing maturity and confidence on the part of the regime, evidenced by its ability to learn from the events of 2011 when over-manipulation led to protests on the streets of Moscow. In 2016 it successfully engineered a supermajority for UR and circumvented a non-systemic opposition response on the streets. Predictions of the regime's imminent demise are therefore somewhat premature and, perhaps, little more than wishful thinking.

Furthermore, I suggest that we may wish to think about the continuing validity of using electoral authoritarianism as a shorthand description of the Russian system: some aspects of the model, notably the role of elections in providing legitimacy, might be questioned in light of the nature of the 2016 parliamentary elections. In the conclusion, I suggest that a "two deflated elections" test might indicate the extent to which the regime may rely less on elections as a form of legitimation and move towards a more straightforward brand of authoritarianism in the future.

The article begins by revisiting the extensive literature on electoral authoritarianism, with a particular focus on the role of elections in such systems. As a framework for discussion it will be argued that elections fulfill the following functions for an electoral authoritarian regime: signaling, co-option of opposition, information, and the provision of legitimation. Before turning to the State Duma election of September 2016 I provide some context to highlight the tactical change of the regime in its approach to electoral politics by providing a brief re-cap of the main features of the 2011 parliamentary contest. I then

5 Alexander J. Motyl, "Lights Out for the Putin Regime: The Coming Russian Collapse", Foreign Affairs, 27 January 2016, New York: Council on Foreign Relations, 2016, https://www .foreignaffairs.com/articles/russian-federation/2016-01-27/lights-out-putin-regime (accessed 4 September 2017); Nikolai Petrov, "Putin's Downfall: The Coming Crisis of the Russian Regime”, London: European Council on Foreign Relations, 2016, available at: http://www.ecfr .eu/publications/summary/putins_downfall_the_coming_crisis_of_the_russian_regime7006 (accessed 4 September 2017). 
discuss the most significant features of the 2016 election. These include the seemingly more liberal trends exemplified by the appointment of Ella Pamfilova as Chair of the Central Electoral Commission (CEC), the sanctioning of opposition participation and the introduction of a more transparent electoral process. I also consider the low-key nature of the campaign itself and the decline in the turnout in comparison with previous elections. Finally, I revisit the theoretical framework to assess the degree to which the 2016 elections were managed in order to sustain the Putin regime.

\section{Revisiting Electoral Authoritarianism}

It is a number of years since any reputable scholar would seek to refer to the Russian political system as democratic, even in its most diminished form. Instead "electoral authoritarianism" has become the common shorthand classification for the Putin regime. ${ }^{6}$ Whilst an electoral authoritarian regime holds regular multi-party elections, the core democratic principles of freedom and fairness are violated to such an extent as to negate the democratic nature of electoral politics, making elections little more than instruments of authoritarian rule. Elections in such systems perform a range of regime-sustaining functions including the provision of a sheen of democratic legitimacy. With the democratic transition paradigm increasingly coming under scrutiny from the late 1990s came the realization that these types of hybrid political system, situated at various points along the continuum from dictatorship to democracy, were here to stay. Such regimes, however labeled, were not simply steppingstones on the road to democratization but were just as, or more, likely to be permanent or semi-permanent phenomena. ${ }^{7}$

As Schedler recognizes, whilst the concept of electoral authoritarianism covers a variety of systems, electoral autocracies can broadly be divided into

6 See, for instance: Archie Brown, "Reading Russia: Forms Without Substance", Journal of Democracy 13, no. 2 (2009): 47-51; Grigorii V. Golosov, "The Regional Roots of Electoral Authoritarianism in Russia", Europe-Asia Studies 63, no. 4 (2011): 623-640; Cameron Ross, "Federalism and Electoral Authoritarianism in Russia", Demokratizatsiya 13, no. 3 (2005): 347-371; Cameron Ross, "Regional Elections and Electoral Authoritarianism in Russia", Europe-Asia Studies 63, no. 4 (2011): 641-662; David White, "Taking it to the Streets: Raising the Costs of Electoral Authoritarianism in Russia", Perspectives on European Politics and Society 14, no. 4 (2013): $582-598$.

7 Thomas Carothers, "The End of the Transition Paradigm", Journal of Democracy 13, no. 1 (2002): $5^{-21}$. 
two sub-sets: competitive and hegemonic. In the former, electoral uncertainty exists. The electoral process is manipulated but is not fully controlled by the ruling party whilst opposition parties retain the capacity to occasionally spring surprise victories despite competing on an unlevel playing field. In contradistinction, a hegemonic electoral authoritarian system is one in which the rulers retain tight control of central state power whilst acting without formal checks and balances. ${ }^{8}$ In such a system, "the ruling party always wins, and is expected to, for it is popular and powerful, and perceived as such". ${ }^{9}$ For Schedler, the hegemonic regime's supermajority is the result of the creation of "over-sized coalitions", providing an "overpowering alliance structure". ${ }^{10}$ In the Russian case, however, supermajority victories for UR have largely been engineered through institutional manipulation and control of the electoral process. Opposition parties remain marginalized, facing the choice of co-option or resignation. Throughout the presidency of Vladimir Putin, the hegemonic model of electoral authoritarianism has increasingly provided the most compelling conceptualization of the Russian system. An underlying theme of this article is to question whether it will continue to do so.

Ultimately, elections are central to such regimes, operating as the vehicles for signaling, co-option, the provision of information and legitimation (as discussed in the following section). However, should the regime's power become so firmly entrenched that it no longer needs to rely on some or all of these functions to sustain that power, then there would be a case for jettisoning the "electoral" prefix and instead simply labeling the regime "authoritarian". Whilst the model of electoral authoritarianism has provided us with a useful descriptor for the Putin regime until 2016, may there be a case for questioning the utility of the model in the wake of the 2016 September elections?

\section{Legitimation and the Persistence of Electoral Authoritarian Regimes}

Whilst there is a wealth of scholarly work explaining the endurance of democratic systems (largely focusing on economic performance and institutional choice), the factors underpinning the stability of hybrid authoritarian systems are less well theorized and documented. Gerschewski makes an important

\footnotetext{
8 Schedler, The Politics of Uncertainty: 105-7.

9 Schedler, The Politics of Uncertainty: 192.

10 Schedler, The Politics of Uncertainty: 193.
} 
contribution to addressing this gap in the literature, proposing that authoritarian regimes are stabilized through a combination of repression, co-optation and legitimation. These three pillars are self-reinforcing and a regime becomes stable once they are institutionalized over time. ${ }^{11}$ We would anticipate that the use of varying degrees of repression to neutralize opposition pressure and the adoption of co-option as a formal and informal tactic to keep elites on board and buy off "semi-opposition" would be important components of the autocrat's toolbox. In contrast, legitimation may seem to play a less obvious role in sustaining an authoritarian regime. However, as Hutcheson and Petersson have argued, in the absence of Weberian legal-rational legitimacy, the Putin regime derives much of its strength from the sustained high levels of popularity for the President. Putin's legitimacy has historically rested on three pillars: economic prosperity; domestic order; and Russia's "great power" aspirations. The decline in economic performance since 2009 has forced the regime to increasingly rely on the latter two pillars. ${ }^{12}$

Legitimation plays a key role in stabilizing authoritarian systems by guaranteeing the active consent of citizens through electoral participation; compliance with the rules; and passive obedience or, at least, toleration of the regime. Drawing on Rousseau's assertion that even the strongest of leaders have to transform strength into right, Gerschewski argues that authoritarian leaders cannot simply rely on abuse of power in the long term but require legitimation in some form to remain in power. ${ }^{13} \mathrm{~A}$ stabilized authoritarian regime is likely to be one that has managed to achieve a balance of the right amounts of repression, co-optation and legitimation. Maintaining the balance between repression and legitimation calls, perhaps, for the greatest dexterity. Repression is a double-edged sword, coming with the potential of undermining the legitimation function. As will be discussed below, the Putin regime struggled to get this balance right in 2011-12 but has since managed to bolster its legitimacy through an overt national-patriotic appeal and the convening of relatively non-contentious parliamentary elections, whilst exercising sufficient repression to neutralize opposition and averting the threat of street protest resulting from the over-use of repressive measures.

\footnotetext{
11 Johannes Gerschewski, "The Three Pillars of Stability: Legitimation, Repression, and Co-optation in Autocratic Regimes", Democratization 20, no. 1 (2013): 13-38.

12 Derek S. Hutcheson and Bo Petersson, "Shortcut to Legitimacy: Popularity in Putin's Russia", Europe-Asia Studies 68, no. 7 (2016): 1107-1126. 


\section{The Function of Elections in Non-democratic Systems}

Whilst theories of democratization focus on the primacy of elections as providing both the means by which citizens hold their rulers to account and as a key indicator of the degree of democratic consolidation, the purpose of elections in non-democratic systems appears less obvious. Yet purpose there is. As Schedler indicates, if elections did not serve a purpose, authoritarian leaders would hardly bother to convene them. ${ }^{14}$ Noting that about three-quarters of all non-monarchical authoritarian regimes since World War II have held national elections, and taking into consideration the costs of mobilizing support and that even the most controlled election contains an element of risk, Geddes infers from their prevalence that they must provide autocratic leaders with benefits that outweigh the costs. ${ }^{15}$ Where an authoritarian regime believes the risk of losing power through elections is more than outweighed by the benefits reaped from holding them and the potential loss of power through more violent means, it will choose the electoral process. ${ }^{16}$

A trawl through the literature on the role of elections in non-democratic systems points to a range of functions they perform in sustaining the regime. To provide a framework for the following discussion of the 2016 Russian parliamentary election, I draw on a model proposed by Gandhi and Lust-Okar that is in turn derived from a thoroughgoing review of the extensive literature. Authoritarian elections, they argue, provide: a signaling mechanism to emphasize the futility of opposition to members of the regime elite; a mechanism for the co-option of systemic opposition; and a source of useful information about both supporters and opponents. Finally, elections play an important role in helping to establish legitimacy both at home and internationally (2009: $405^{-6) .} \cdot{ }^{17}$

The first of these functions, signaling, relies on emphatic, supermajority electoral victories to make clear to members of the political elite that there is no political future outside the regime's chosen party, thereby deterring any

\footnotetext{
14 Schedler, The Politics of Uncertainty: 143.

15 Barbara Geddes, "Why Parties and Elections in Authoritarian Regimes?", presented at the Annual Meeting of the American Political Science Association, Washington DC, 2005, http://www.daniellazar.com/wp-content/uploads/authoritarian-elections.doc (accessed 4 September 2017).

16 Henry E. Hale, Patronal Politics. Eurasian Regime Dynamics in Comparative Perspective (Cambridge: Cambridge University Press, 2015): 69 .

17 Jennifer Gandhi and Ellen Lust-Okar, Ellen "Elections Under Authoritarianism", Annual Review of Political Science, 12 (2009): 403-22.
} 
would-be defectors. ${ }^{18}$ Signaling goes beyond a simple enforcing of elite unity however; it also sends out a message to the general public. As Magaloni notes, by holding regular elections, winning these convincingly, and by "painting the streets and towns all over the country in the party's colors", the Mexican PRI was able to generate an image of invincibility. ${ }^{19}$ Similarly, anyone who has visited a major Russian city at election time in recent years will testify to the ubiquity of UR or Putin posters adorning the streets, not to mention the favorable wall-to-wall media coverage. Supermajority electoral victories therefore not only serve to enhance elite cohesion; they also serve to highlight the futility of organized non-systemic opposition.

Emphatic electoral victories may provide a crucial show of strength for the authoritarian regime but they do run the risk of freezing out passive and nonregime-threatening opposition parties. The second function of authoritarian elections therefore is to play a co-opting role. Some opposition parties may be allowed to compete, providing their leaders with possibilities of political advancement and access to resources. Importantly, such opportunities are unlikely to be conferred on all opposition parties. Co-option therefore also serves as a tried and tested means of divide-and-rule. ${ }^{20}$ Some parties choose the role of "loyal opposition", leaving others to rebel on the margins. Through selective co-option of opposition forces, the authoritarian regime pre-empts any possibility of a threat from a united front. ${ }^{21}$ This has certainly been the case in Russia since 2003 with the loyal or "systemic" opposition ${ }^{22}$ in the form of the Communist Party of the Russian Federation (CPRF), the Liberal Democratic Party of Russia (LDPR) and A Just Russia (AJR) receiving preferential treatment from the regime in return for their acquiescence, leading to the development of a parliamentary cartel. ${ }^{23}$ More repressive measures against the

18 Merete Bech Seeberg, "State Capacity and the Paradox of Authoritarian Elections", Democratization 21, no. 7 (2014): 1265-1285.

19 Beatriz Magaloni, Voting for Autocracy: Hegemonic Party Survival and its Demise in Mexico (New York: Cambridge University Press, 2006): 9.

2o Gandhi and Lust-Okar, "Elections Under Authoritarianism": 405.

21 Magaloni, Voting for Autocracy: 10.

22 The terms "systemic" and "non-systemic" opposition, although widely used to conceptualise Russian party politics, have become, I believe, increasingly become outdated concepts. It makes rather more sense to think in terms of systemic and non-systemic parties. The latter, by operating outside the system are de facto opposition parties whilst the former, either overtly or covertly, supporting the regime are not part of the political opposition. See David White "Re-conceptualising Russian Party Politics", East European Politics 28, no. 3 (2012): 210-224 for a discussion of the Russian party system.

23 Derek S. Hutcheson, "Party Cartels beyond Western Europe: Evidence from Russia", Party Politics 19, no. 6 (2013): 907-924. 
"non-systemic" opposition not only prevent a real opposition threat but also send a warning signal to the Kremlin-friendly parties of the dangers of overt opposition to the regime.

The third role of elections is that of providing the regime with valuable information about the relative strengths and weaknesses of its own support and of support for potential oppositional threats. ${ }^{24}$ Elections provide the regime with a regular snapshot of the state of the political elites, the state's apparatus and wider political and civil society, allowing it to identify and pre-empt potential conflicts. ${ }^{25}$ Campaign performance also indicates the competence and loyalty of those charged with engineering a supermajority for the regime's preferred party. As will be noted in the following discussion, the Russian regime's dissatisfaction with the campaign tactics and outcome of the 2011 parliamentary elections led to a change in personnel and to a very different approach to the 2016 elections.

Finally, as noted above, authoritarian regimes cannot simply rely on repression to remain in power and instead need to build a basis of legitimation. It should not surprise us, therefore, that a final function of authoritarian elections is to endow the regime with at least a façade of legitimacy. Authoritarian elections may be closely controlled and their outcomes largely pre-determined, but they do serve to suggest both domestically and internationally that they are dependent to some extent on popular will. ${ }^{26}$ Electoral authoritarian regimes may indeed subvert the principle of popular consent but they are nonetheless keen to invoke that principle for the purposes of legitimation. ${ }^{27}$

We will return to these electoral functions in the following section on the 2011 and 2016 parliamentary elections; but as the legitimating mechanism will be a key point for discussion, its role requires further elaboration here.

\section{Authoritarian Elections and Legitimacy}

Before discussing legitimacy in an authoritarian setting we do need to be clear that many authoritarian regimes are likely to be as or more concerned with

24 Gandhi and Lust-Okar, "Elections Under Authoritarianism": 405, Magaloni, Voting for Autocracy: 9.

25 Vladimir Gel'man, "The Rise and Decline of Electoral Authoritarianism in Russia", Demokratizatsiya 22, no. 4 (2014): 503-522; Geddes, "Why Parties and Elections?".

26 Gandhi and Lust-Okar, "Elections Under Authoritarianism": 406.

27 Andreas Schedler, "The Logic of Electoral Authoritarianism" in Andreas Schedler ed., Electoral Authoritarianism: The Dynamics of Unfree Competition (Boulder: Lynne Rienner, 2006): 1-23. 
cultivating domestic rather than international legitimacy. In the Russian case, the holding of slightly more transparent elections may result in slightly kinder headlines in the West, but is hardly guaranteed to bolster the regime's international standing, especially at a time of tensions over Russian policy in Syria and Ukraine. As Baunov states, however, for the Russian regime, electoral legitimacy is not about looking good in international society. To seek to do so would be "the equivalent of trying to sneak into a grand party wearing a counterfeit Brioni tie". Instead the Kremlin's claim to power is dependent on institutional legitimation and the confirmation that the regime has genuine popular support electorally validated by the people. The first priority of any regime is to appear legitimate in the eyes of its own public. ${ }^{28}$

In his seminal study of the "menu of manipulation", Schedler takes it as read that elections are the agents of legitimacy for authoritarian regimes. ${ }^{29}$ Developing this theme later, Schedler refers to the various sources of legitimacy for the authoritarian ruler (revolutionary, transcendental, traditional, communitarian, charismatic and substantive) before concluding that "popular consent carries the day". ${ }^{30}$ Through the holding of multi-party elections, the electoral authoritarian regime institutes the principle of popular consent even if this is subverted in practice. Such a regime aims to "reap the fruits of electoral legitimacy without running the risk of democratic uncertainty". ${ }^{31}$

Pointing to the example of the relatively transparent and genuinely competitive 2013 mayoral election in Moscow (the opposition candidate, Aleksei Navalny, gained 27 percent of the vote and almost forced a run-off with the UR incumbent and Putin loyalist, Sergei Sobyanin), Gill suggests that the Putin regime is wedded to the electoral mode of legitimation, "if only because this enables them to continue to tap into the international norm of democracy as a claimed basis of regime authority". ${ }^{32}$ Sergei Markov, a political consultant with close ties to the Kremlin, ${ }^{33}$ agreed that the main goal in 2016 was that the elections be viewed as legitimate in order to deprive the opposition of the

28 Alexander Baunov, "Authoritarianism by Stealth: Russia After the Duma Elections", Moscow: Carnegie Moscow Center, 21 September 2016, http://carnegie.ru/commentary/?fa= 64647 (accessed 21 September 2016).

29 Andreas Schedler, "The Menu of Manipulation", Journal of Democracy 13, no. 2 (2002): $36-50$.

$30 \quad$ Schedler, "The Logic of Electoral Authoritarianism": 13.

31 Ibid., 37.

32 Graeme Gill, Building an Authoritarian Polity: Russia in Post-Soviet Times (Cambridge: Cambridge University Press, 2015): 108.

33 Markov was a United Russia State Duma deputy from 2007-2011; a member of Russia's Public Chamber from 2006-2008 and has served on presidential commissions. 
opportunity to mobilize support, as had been the case in 2011. Not only were the authorities not standing in the way of opposition candidates, they were actively helping them to ensure the results were not tainted. ${ }^{34}$ Such elections, of course, have to be managed to minimize the risk of them becoming genuinely competitive. As Bacon notes, at the heart of electoral authoritarianism in Russia is the realization that the electoral framework can be manipulated in order to shield the regime from significant challenges and keep it in power. ${ }^{35}$ Discussing the use of the electoral process as a key means of legitimating the dominance of the People's Action Party (PAP) in Singapore, Morgenbesser concludes that the Singaporean electoral system has been "free enough for citizens to confer legitimacy, but unfair enough to ensure the PAP's dominance". ${ }^{36}$ As will be discussed below, achieving this balance, one that is integral to maintaining the authoritarian regime's dominance, was at the heart of the Kremlin's strategy in 2016.

There is an inherent paradox here, however. Elections in Russia have become synonymous with manipulation, ballot rigging and coercion. Why then does a regime so keen to "reap the fruits of electoral legitimacy" risk doing so through the overt use of electoral manipulation? Bacon identifies three possible explanations. Firstly, although the election process itself operates, in part, to exhibit the strength of the regime through the engineering of supermajorities for its favored candidates or parties, the control exerted over the electoral system and beyond by the regime cannot be allowed to slip, for fear of making it appear weak. Secondly, since the "Orange Revolution" of 2004, the Putin regime has feared "Ukrainization" through allowing "too much" competition. There is therefore a trade-off between restraining from overt manipulation in order to enhance legitimacy whilst allowing some illegitimate activity to be revealed to exhibit the regime's capacity to show its strength through exerting control of the electoral process. A third explanation, and one not directly emanating from the regime itself, is the possibility that much of the electoral fraud that has taken place is not directly sanctioned by the regime but is instead the

34 Henry Meyer and Irina Reznik, "Putin's Election Grip Is So Tight Even His Nemesis Can Take Part”, Bloomberg, 26 August 2016, https://www.bloomberg.com/news/articles/2016-08-23/ putin-s-election-grip-so-tight-even-khodorkovsky-can-take-part (accessed 1 September 2016).

35 Edwin Bacon,"Electoral Manipulation and the Development of Russia's Political System”, East European Politics, 28, no. 2 (2012): 105-118.

36 Lee Morgenbesser, “The Autocratic Mandate: Elections, Legitimacy and Regime Stability in Singapore", The Pacific Review 30, no. 1 (2016): 205-231. 
results of regional authorities over-enthusiastically over-fulfilling the quota in order to please their political masters. ${ }^{37}$

The electoral mode of legitimacy carries with it an inherent threat to the authoritarian ruler and treading the tightrope between too much and too little manipulation whilst attempting to cultivate legitimacy may call for a good deal of finesse. ${ }^{38}$ Whilst risks are attached, authoritarian regimes choose to hold elections so long as they calculate the risk of losing power to be outweighed by the benefits to be gained by holding elections and by the risk of a more catastrophic loss should they not hold elections and lose power through less institutionalized and possibly violent means. ${ }^{39}$ However, simply holding elections is not sufficient to bolster the authoritarian regime's legitimacy. Elections lacking in substance may undermine the functions outlined above. In parliamentary elections, the regime's favored party does not just have to win - it has to win big. High turnouts and supermajorities are required. Not only do these enhance the legitimacy of the regime they are also a show of regime strength by demonstrating that the regime has the resources to distribute goods, punish any regions that vote against it and control the flow of information. ${ }^{40}$ Moreover, as noted above, supermajority victories signal regime invincibility. If opposition success is seen as highly improbable, regime elites will stay on board whilst vacillating opposition forces may be attracted by the prospect of co-option. ${ }^{41}$

\section{The Changing Face of Electoral Politics in Russia: The Mismanaged Elections of 2011}

Whilst the protests during the winter of 2011-12, following the parliamentary elections in December, took many by surprise (not least the regime itself) they were not entirely unexpected. Opposition activists had been planning a campaign for fair elections as early as the autumn of 2010. ${ }^{42}$ Moreover, public disquiet with the regime had been growing since Putin and Medvedev jointly

37 Bacon, "Electoral Manipulation": 114.

38 Schedler, The Politics of Uncertainty: 259-294.

39 Hale, Patronal Politics: 69.

$40 \quad$ Geddes, “Why Parties and Elections?": 20.

41 Seeberg, "State Capacity": 1270.

42 In an interview with the author (4 November 2010), Vsevelod Chernozub, a member of the Solidarity movement's political council, stated that the movement was then in the process of building a coalition "to protest against the falsification of elections, with the slogan 'For Fair Elections". 
announced at a UR congress in September 2011 that the latter would be stepping aside to allow the former to stand for a third presidential term in March 2012. The December election was notable for two reasons: the slump in support for UR, in part the result of a vigorous "vote for anyone except UR" campaign led by Aleksei Navalny; and the clear evidence of widespread electoral violations on a grand scale.

Immediately after the election, spontaneous protests broke out in Moscow and throughout Russia. All were unsanctioned by the authorities and all were swiftly broken up. Well-known opposition activists such as Ilya Yashin, Sergei Udaltsov and Aleksei Navalny, were arrested and given short custodial sentences. At this stage the regime assumed its coercive capacity would be sufficient to deter further challenges. However, when over 30,00o people signed up on social networking sites for a protest rally in Moscow on 10 December 2011, the authorities were forced to agree to sanction the demonstration. On the day, Russia witnessed the largest opposition protest since the collapse of communism with over 100,000 estimated to have taken part. ${ }^{43}$ Further large-scale protests took place in Moscow later in December and again in February. Again, faced with the alarming prospect of large numbers taking to the streets the authorities accepted that the costs of suppressing the Moscow protest in terms of both domestic and international reaction were prohibitively high.

Not only did the protests take the regime by surprise, its response was nothing like as assured or coherent as in the past. Putin attempted a joke, calling the protesters "Bandar-Logs", the tribe of monkey people in Rudyard Kipling's "The Jungle Book". ${ }^{4} \mathrm{He}$ also quipped that when he had seen protesters wearing white ribbons he had thought they were condoms and that the protesters were taking part in an anti-AIDS march..$^{45}$ The joke backfired when demonstrators took to the streets with posters showing Putin swathed in a giant condom. In a further twist, Putin even suggested Western interests were behind the protests, accusing U.s. Secretary of State, Hillary Clinton, of personally instigating the protests. Later, after the initial shock, both Medvedev and Putin spoke in more measured tones. Medvedev suggested the protests were evidence of Russian

43 Elena Kostyuchenko, "Bolotnaya Ploshchad >10000o", Novaya Gazeta, 10 December 2011, https://www.novayagazeta.ru/news/2011/12/10/52372-bolotnaya-ploschad-100000 (accessed 7 September 2017).

44 Guy Faulconbridge, "Analysis: Russia's Putin risks losing touch amid protests", Reuters, 26 December 2011, http://www.reuters.com/article/us-russia-putin-idUSTRE7BPoGH2o11 226 (accessed 4 September 2017).

45 "Liniya Putina: Prem'er otvetil na voprosy rossiyan", Rossiiskaya Gazeta, 16 December 2011, https://rg.ru/2011/12/16/liniya.html (accessed 1 September 2017). 
democracy developing whilst Putin argued that the protests were the result of growing prosperity and that people were better educated and therefore more critical. Eventually the protest movement ran out of steam. Putin's re-election as president in March 2012 took the sting out of the opposition's tail and after a return to violent coercion at the infamous rally at Bolotnaya Square on 6th May 2012 on the eve of Putin's inauguration, protest activity declined still further.

The 2011 election and its aftermath were, however, hugely damaging to the Putin regime in terms of signaling and legitimation, reflecting in declining approval ratings for Putin. ${ }^{46}$ The signal sent out to members of the political elite appeared to be that the Kremlin had lost its touch when it came to managing elections. The 2011 election had been badly managed and the appearance of large numbers of protesters on the streets of the capital, openly taunting the leader, suggested that the potential for an opposition challenge was not as farfetched as had previously been imagined. This is why the ruthless and violent suppression of the Bolotnaya protest was necessary: this was the regime signaling to the elites that it still had sufficient coercive capacity to maintain order and close down opposition. The regime's legitimacy, however, took a battering from both the electoral outcome and the subsequent protests. The increased level of manipulation might, on one hand, have signaled a degree of control, but the fact that, even with outright electoral fraud, the regime was unable to engineer a supermajority for UR in the face of a concerted opposition campaign seriously undermined its legitimacy in the eyes of regime elites. Whilst the sanctioning of mass protest might have sent out messages that the regime was open to liberalization, its return to suppression at Bolotnaya threatened to undermine its legitimacy with the Russian public and externally.

\section{6 - Getting it Right: "boring elections with cheerful results"}

It is clear that the regime learned important lessons from the 2011-12 electoral cycle. Then, Moscow had been the focus for demonstrations with few and relatively sparsely attended events taking place elsewhere. In 2016, therefore, the overt use of manipulation in the capital was to be avoided, with the aim of greatly diminishing the potential for an opposition challenge. The two go hand-in-hand: an apparently cleaner and more transparent electoral process provides fewer opportunities for opposition actors to mobilize support for

46 Having enjoyed approval ratings of over 80 per cent prior to the 2011 election, Putin's ratings "slumped" to the low sixties and did not return to their former heights until 2014. See www.russiavotes.org (accessed 4 September 2017). 
protests. Allowing opposition parties to participate, and be soundly defeated in the election, would signal the dominance of the regime and the futility of opposition. This is exactly what happened in September 2016. Rather than overrelying on the manipulation of the polling process (through the usual methods of ballot-stuffing, "carousel voting" and dubious counting procedures) with the concomitant risk of protests, the groundwork was carried out well in advance of election day on 18 September.

Firstly it should be noted that the post-Crimea political landscape, which saw a sustained increase in the President's poll ratings, was hardly going to favor opposition parties such as Yabloko and the Party of People's Freedom (PARNAS) that had publicly opposed the annexation and had been critical of the regime's policy towards Ukraine more generally. Moreover, the opposition was continually discredited in the run-up to the elections, an example being the leaked video of PARNAS leader, Mikhail Kasyanov, caught in flagrante delicto in a hotel room with his personal assistant. It should also be noted that the "democratic opposition" did itself no favors as a result of its innate ability to shoot itself in the foot at the most inappropriate juncture through internal squabbles and its perennial failure to unite in any meaningful sense.

The regime signaled its intentions to run a more transparent electoral process with the appointment of former human rights ombudsman, Ella Pamfilova, to head the CEC, replacing the notorious Vladimir Churov. The latter will always be remembered for announcing in 2007 that "Churov's Law No.1" was that "Putin is always right". ${ }^{77}$ On taking up the post, Pamfilova, a former Duma deputy, a presidential candidate in 2000 and a politician with liberal credentials, stated that she intended to tackle electoral fraud. Web-cams had already been installed in the majority of polling stations for the 2012 presidential election in response to concerns about violations in the 2011 parliamentary election and Pamfilova heralded the use of this technology as central to her clean-up campaign. ${ }^{48}$ This was also to be a more open contest. Fewer restrictions were placed on opposition parties. PARNAs, for instance, which had been prevented from running in 2011 on the basis of rather spurious registration

47 Andrei Kolesnikov, "Razve Putin mozhet byt neprav?", Kommersant, 9 April 2007, https:// www.kommersant.ru/doc/757109 (accessed 4 September 2017).

48 Peter Hobson, "Legitimized Elections: The Kremlin Plays a New Game", Moscow Times, 10 March 2016, https://themoscowtimes.com/articles/legitimized-elections-the-kremlin -plays-a-new-game-52118 (accessed 4 September 2017). In the event, the responsibility for web-cams was left with regional and local authorities and their installation was not as widespread as had been the case in 2012. 
technicalities, was able to participate, albeit in a weakened position following the damaging revelations about its leader.

The election, originally scheduled for December 2016, was brought forward to September, meaning that the campaign itself would be run whilst many Russians were on holiday. The outcome was a remarkably low-key and short campaign. Opinion polls taken in July showed that only a third of the Russian public was aware that elections were to be held in September. Gel'man views this as a deliberate ploy aimed at decreasing public interest in the election with a lower turnout being outweighed by restricting opportunities for negative campaigning. ${ }^{49}$ Reports highlighted the absence of election posters on the streets and the lack of televised debates between candidates running in singlemember districts. Mikhail Zubov noted that the federal budget allocation for the election had been slashed and that twice as much was spent on installing webcams at polling stations than on the entire campaign itself. This may have been important for Putin's legitimacy, noted Zubov, but showed that the legitimacy of the State Duma was seen by the regime as far less important. ${ }^{50}$

Whilst the appointment of Pamfilova and the much-publicized use of webcams may have been designed to make the election appear more transparent, a report by the independent election-monitoring agency, Golos, cast doubt on the claim. The agency suggested that the authorities had indeed learned from the mistakes of 2011 and had taken a number of steps ahead of the election to mitigate and minimize public scrutiny and oversight of the electoral process. These steps included legislation forcing organizations in receipt of foreign funding such as Golos to register as "foreign agents"; obstruction of access to polling stations for observers and a concerted media attack on public observers and independent experts. The agency noted that in 2016 there were half as many independent observers on election day than in $2011 .{ }^{51}$

Finally, in contrast to the 2011 election, the outcome was uncontested. There was to be no repeat of the large-scale street protests of the "Moscow Winter", indeed there were to be no protests of any kind. Alexander Baunov of the Carnegie Centre described the conduct and outcome of the September 2016

49 Vladimir Gel'man, "2016 in Review: Russian Domestic Politics", Russian Analytical Digest 195 (2016): 16-18, http://www.css.ethz.ch/content/dam/ethz/special-interest/gess/cis/ center-for-securities-studies/pdfs/RAD195.pdf (accessed 4 September 2017).

5o Mikhail Zubov, “Chego khochet vlast': privlech' izbiratelya ili otpugnut' ego?", Moskovsky Komsomolets, 30 August 2016, http://www.mk.ru/politics/2016/o8/29/kak-putin-budet-re gulirovat-yavku-na-vybory-v-gosdumu.html (accessed 4 September 2017).

51 "GOLOS On Duma Elections: Far From Being Free and Fair" (2016) Russian Analytical Digest 189: 9-10. http://www.laender-analysen.de/russland/rad/pdf/Russian_Analytical _Digest_189.pdf (accessed 6 September 2017). 
election as evidence of the "Volodin Spring", referring to Vyacheslav Volodin who had replaced the "grey cardinal", Vladislav Surkov, as deputy head of the presidential administration after the botched operation of and response to the December 2011 election. The rejection of overt manipulation and coercion associated with Surkov's handling of the previous election had been replaced by a far more sophisticated approach. The 2016 election was still managed tightly by the Kremlin, but in a more nuanced fashion. ${ }^{52}$

To return to the model of Gandhi and Lust-Okar, it is clear that the 2016 parliamentary election performed the signaling, co-opting, informational and legitimizing functions central to the sustenance of the regime. The engineering of a supermajority for UR clearly sent out a strong signal to political elites that the regime was firmly in control after the shaky handling of and response to the 2011 election. The marginalization of non-systemic opposition parties served to act as a deterrent to any new or returning Duma deputies who may have had thoughts of adopting even the mildest of critical stances against the regime. The defeat of former AJR deputy and fierce critic of the regime, Dmitry Gudkov (running in 2016 on the Yabloko ticket) was a particularly symbolic signal. Gudkov had earned the reputation as the only opposition figure of any substance in the previous convocation of the Duma. The electoral outcome not only saw the enhancement of UR's dominant position in the State Duma but also was further evidence of the ability of the regime to co-opt the "loyal opposition" parties and entrench the existing parliamentary cartel. In terms of the election's informational role, although the regime was already well aware of the relative strengths and weaknesses of its own support and that of the opposition, the electoral outcome confirmed the continuing frailty of an opposition lacking unity and leadership. With his party side-lined by the CEC, Aleksei Navalny was unable to build on his impressive performance in the 2013 mayoral contest in Moscow. Finally, as has been noted, the regime's favored party did not just win, it won big. Whilst the low turnout potentially might have undermined regime legitimacy, this was more than offset by UR's supermajority.

\section{Concluding Thoughts: The Continuing Maturation of the Putin Regime and the Finessing of Electoral Authoritarianism?}

To return to the first of the paper's key questions, what does the September 2016 parliamentary election tell us about the health of the Putin regime, as Russia heads towards the 2018 presidential election? The regime engineered 
a low-key campaign and was seemingly unconcerned with the concomitantly low turnout. The literature discussed above would suggest that this may be damaging to the legitimacy of the regime, both high turnouts and supermajorities being required both for signaling and legitimation purposes. Here, I suggest the regime acted with typical Putin pragmatism. Having learned valuable lessons from 2011 about the dangers of overt manipulation to achieve both a high turnout and a supermajority, what happened in 2016 was essentially a trade-off. The election was held early, participation was not encouraged, and opposition parties were allowed to stand. As a result, there was less need for manipulation and fraud and subsequently, fewer grounds for protest. An electoral authoritarian regime may well have a preference for high turnouts and supermajorities, but avoiding protest with the possibility that such events may trigger an existential crisis are even more vital in maintaining the regime. ${ }^{53}$

In any event, a supermajority for UR was achieved. Without a repeat of anything like the "vote for any party except UR" campaign of 2011, the party of power increased its share of the vote (albeit only by just under 5 percent) and greatly increased its share of Duma seats (from 238 to 343), more than compensating perhaps for the potential loss of legitimacy as a result of the significantly lower turnout (63.7 percent in 2007, 60.1 percent in 2011 and 47.9 percent in 2016). This suggests that, for an electoral authoritarian regime, supermajorities may only desirable where their production is not likely to cause significant trouble. Another important lesson learned from 2011 is that it is far better to allow opposition forces to compete (having ensured they do so from a weakened position) and to defeat them soundly at the ballot box rather than to prevent them from standing, effectively encouraging them to resort to street protest. Should the "non-systemic" opposition manage to coalesce into a coherent and effective political organization ahead of the next Duma election then the apparently inclusive strategy may have to be further refined possibly by a resort to more familiar divide-and-rule tactics.

I have also argued that the engineering of the perception of relatively transparent election point to evidence of the "Volodin Spring" and a tactic aimed at heading off any potential opposition protest about the conduct of the election. As Bader notes in this issue, ${ }^{54}$ the election was not as clean as Pamfilova had claimed it would be. Despite the installation of web-cams in polling stations

53 It should be noted, however, that low turnout and lack of supermajority is one thing in parliamentary elections, but quite another when it comes to presidential elections where the legitimacy of the incumbent president is more directly at stake. 
there was evidence of fraudulent activity, particularly ballot-stuffing albeit on a reduced scale from previous elections. The revealing of a certain amount of fraud may, however, serve two useful purposes for the regime. On one hand it might suggest to internal and external observers that it takes the problem seriously to the extent that it actively exposes fraud through more open electoral processes. Secondly, however, allowing a certain amount of fraud also signals to anyone who might have felt the regime was "going soft" that it still retains the capacity to use more hard coercive measures if necessary.

As for the health of the Putin regime therefore, far from being unstable and facing imminent collapse without dramatic change ${ }^{55}$ the way in which it successfully managed the 2016 parliamentary election suggests instead that it is a mature, adaptive and confident regime. Mass protest, not electoral defeat is the primary threat to an electoral authoritarian regime. Being able to circumvent potentially destabilizing protest may well offset the risk of losing legitimacy through the low turnout.

Finally, what does the election tell us about the nature of the regime? Does electoral authoritarianism remain the most appropriate conceptualization or does the regime's approach to the election suggest that it is less reliant on the electoral process as a vehicle to sustain its dominance? To paraphrase Zhou Enlai, it is probably too soon to tell. As has been demonstrated, the failure to engineer a high turnout and to produce a supermajority in vote share can be compensated by a supermajority in seat share, especially if this shows the ability (in this case at least) to manipulate the electoral system to secure regime advantage and dominance. The engineering of a single low-key parliamentary election campaign does not necessarily point to anything beyond the regime's desire not to repeat the mistakes of 2011. However, if this were to be repeated in more than one election it might suggest that it is indeed time to jettison the "electoral" prefix and signal that the regime is moving to a more straightforward authoritarianism. Before reaching a conclusion on whether Russia is moving away from the electoral authoritarian model, therefore, further evidence of the regime's declining reliance on elections, particularly as a vehicle for legitimation, is required. Indeed, we may need to wait for the next scheduled parliamentary elections of 2021 to apply what might be called a "two deflated elections" test. ${ }^{56}$ Should we see a repeat of the 2016 strategy it might suggest that the regime was indeed aiming to shift legitimation away from elections rather than just responding to its protest problem from 2011-12. If elections cease to perform the role of providing the regime with legitimacy,

55 Petrov, "Putin's Downfall".

$5^{6}$ I am indebted to Neil Robinson for suggesting the "two deflated elections" concept. 
we may need to think of the Russian regime simply as "authoritarian" without any qualifying prefixes.

For the time being, however, electoral authoritarianism retains a degree of validity as a working conceptualization of the Russian political system. We can see how elections in Russia still, to a degree, serve as a signaling mechanism. Elections continue to provide information about supporters and opponents; and operate as a mechanism for the co-option of "systemic" opposition parties. Above all though it is the focus on legitimation that has been challenged in this paper. The conduct of the 2016 parliamentary election may well signal a significant change in the nature of the Putin regime but we may have to wait for the "two deflated elections" test to draw more concrete conclusions. 